This is the Accepted Version of an article which will be published by Wiley in Journal of Agrarian Change: http://onlinelibrary.wiley.com/journal/10.1111/(ISSN)14710366

Accepted Version downloaded from SOAS Research Online:

http://eprints.soas.ac.uk/22393/

\title{
Introduction to the Special Issue
}

\section{The Political Economy of Agrarian Change: Essays in Appreciation of Henry Bernstein}

\section{LIAM CAMPLING AND JENS LERCHE}

This special issue presents five essays and an interview in appreciation of Henry Bernstein. The essays - by major scholars in the field of agrarian political economyengage with different aspects of Bernstein's oeuvre: from direct critical reflections on his approach to the peasantry and the agrarian question through to arguments developed in connection to his work on commercial capitalism, landed-property and the relationship between petty production and accumulation. This introduction briefly sets out some of the major aspects of Bernstein's distinctive editorial, pedagogical and theoretical contributions. It suggests that his most crucial and lasting contribution is in his absorption and ability to apply Marx's theory and method as a living theoretical and analytical approach to the study of agrarian political economy.

Key words: peasant studies, agrarian political economy, Marxism

This special issue of the Journal of Agrarian Change is a festschrift for Henry Bernstein. There are good reasons to celebrate the oeuvre of Henry Bernstein. His contributions to peasant studies, agrarian political economy and development studies are extremely significant, from his seminal 1977 paper 'Notes on Capital and Peasantry' onwards. His book Class Dynamics of Agrarian Change (Bernstein 2010a) has been translated into Bahasa, Chinese, French, Japanese, Portuguese, Spanish, and Turkish, and serves as a textbook for students of agrarian political economy in many

\footnotetext{
Liam Campling, School of Business and Management, Queen Mary University of London, Mile End We would like to thank the contributors to this special issue, the peer reviewers, and Cristóbal Kay and Bridget O'Laughlin for their comments on this introduction. The usual disclaimers apply.
} 
corners of the world. With Terence J. Byres, he led and nursed what are now the main spaces for debate in agrarian political economy and political sociology - founding this Journal in 2001 and editing it for seven years, and before that joining Byres in 1985 as co-editor of the Journal of Peasant Studies where they worked together for 15 years. ${ }^{1}$ The intellectual energy and editorial guidance of Bernstein and Byres contributed to shaping generations of scholars, pushing them that bit further and demanding a level of rigour that only scholars of their calibre can command. ${ }^{2}$ But most importantly, perhaps, Bernstein's razor sharp class-based political economy has made its mark across a wide set of analytical fields and debates during the last half century. An indication of the breadth and depth of his interventions is apparent with only a cursory review of the list of his published work to-date, which is detailed in full at the end of 'An interview with Henry Bernstein' by Gavin Capps and Liam Campling.

To Bernstein, Marxist political economy is in the blood, not as dogma or tradition but as a living theoretical and analytical approach. As we learn in the interview, he cut his teeth in communist debate in a politically-active family, at the LSE in the late 1960s and, crucially, in Dar as Salaam in the late 1970s when he began seriously his work on thinking about the peasantry and capitalism. Bernstein pushes the boundaries of how we think about agrarian issues and class relations and struggles. He has become an example to follow for many, while also ruffling a fair few feathers among both fellow political economists and those not taking a classbased approach. From the onset he was fiercely critical of both the Warrenite argument (Warren 1980) on the overwhelmingly progressive nature of capitalist development in Africa, Asia and Latin America on the one hand, and of Third Worldism and dependency theory on the other. As capitalism entered the era of neoliberal globalisation, he argued that this meant the end to country-based capitalist solutions to the agrarian question, changing the potential for national class alliances for land reforms. This put him at odds with close colleagues also rooted in agrarian political economy. Bernstein argues against agrarian populism, with its obfuscation of ever deeper class divides within rural populations, and against what he sees as

\footnotetext{
${ }^{1}$ The intellectual quality of their long-standing friendship and professional collaboration is evident in the continued 'conversation' between them on method, the transition and the agrarian question, which is developed further in Byres' essay in this special issue.

${ }^{2}$ Byres' contribution to the field was recognized in a festschrift in Journal of Peasant Studies (Bernstein and Brass 1996).
} 
erroneous and mechanical predictions of full-scale proletarianization in the global South. Throughout this, he continues to develop his own analysis of present-day capitalism as it is unfolding in different places, with a sharp eye on the role of and implications for agrarian classes of labour, from the initial focus on the peasantry under capitalism and class relations and politics in Africa, to issues such as the agrarian questions for labour and capital, the by-passing of the agrarian question of capital at the national level, the global farming complex, productive forces and the environment, and food sovereignty. Crucially, Bernstein's theoretical approach had from the outset to confront the politics of gender. And as Bridget O'Laughlin points out in this special issue, he responded to criticisms by feminist political economists of his conception of gender in Africa as reflecting a pre-capitalist relation of domination and changed his thinking to consider how class, gender and other social divisions are (re)produced and interplay under capitalism.

Bernstein's intellectual curiosity and willingness to take seriously positions different to his own make his insights relevant also for those with whom he disagrees. His engagements with classic scholars such as Alexander Chayanov and with proponents of Via Campesina and food sovereignty are cases in point. He acknowledges what he sees as the partial insights into the peasantry of Chayanov, just as he recognizes the importance of the social movement critique of the existing global food regime, but he does so while criticizing their analytical and political shortcomings, shortcomings which arise from their clubbing together of different agrarian classes into the undifferentiated category 'the peasantry'. He is one of the few class-based agrarian political economists that has a voice in these sometimes heated and certainly politically crucial debates. Take for example Bernstein's recent 'sceptical view' of food sovereignty (2015), which has generated sympathetic engagement and synthetic extension (Jansen 2015) and critical polemic (McMichael 2015).

The importance of pedagogy to Bernstein's intellectual formation comes through prominently in the interview. His particular theoretical take on the peasantry and petty commodity production (PCP) was developed through interactions with young people originating from the Tanzanian countryside in the 1970s when trying to illuminate and (crucially) activate Marx's categories in the critique of political economy (see O'Laughlin in this issue). Political commitment to and through pedagogy continued with involvement in the Open University in the early 1980s, 
which pioneered distance learning materials for non-'traditional' students. This laid the basis for his contributions to the writing of textbooks on development studies, which were themselves serious intellectual interventions influencing generations of students (e.g. Bernstein et al. 1992; Bernstein 2000). His reflections on development studies and social theory in the 2000 s offer a searchlight to pierce through the layered fog of ever-greater policy-centrism and the technical specifications feeding into 'rule by experts' on the one hand and the political retreat into fragments of - and fragmenting? - identity concerns on the other.

To list Bernstein's main scholarly achievements and breakthroughs here could not do them justice. Many of them are contextualized in the interview that follows and are engaged with in the articles of this special issue. In the early 1970s he engaged in scathing attacks on modernization theory, and sympathetic Marxist critiques of dependency theory and World Systems Theory. But he really hit the academic headlines with a cluster of papers published between 1977 and 1981 in Review of African Political Economy and Journal of Peasant Studies. The first of which 'Notes on capital and peasantry' - forms the springboard for Jairus Banaji's contribution to this special issue. He further refined his distinctive take on African peasantries and PCP in the 1980s - again showing his willingness to respond to critique, which is explored in the interview. The theme of petty commodity production is examined and developed in the contributions by Barbara Harriss-White and O'Laughlin published here, and it is also a central methodological starting point for Gavin Capps' article which seeks to fill an important gap in African agrarian political economy through his category of 'tribal landed-property'.

Bernstein developed an active interest in land politics in South Africa during the period of end-game for apartheid in the early 1990s and made a series of important analytical interventions. He engaged in debates on the politics of land reform in South Africa - putting it in historical perspective - and made political connections with the Left. He also undertook an important study of commercial maize production by white capitalist farmers producing food for the black labouring classes. This included forays into the filière or commodity chain (Bernstein 1996a) and a further development of his understanding of agribusiness, including through Chayanov (e.g. Bernstein 2009a). Themes that the articles by Banaji, Harriss-White and O'Laughlin develop in different ways. 
From the mid-1990s Bernstein deepened his engagement with debates, theories and implications of the 'agrarian question', and this is still on-going (Bernstein 2016). It was triggered by the work of Terry Byres $(1991,1996)$ and continues to spark debate into the 2010s. ${ }^{3}$ A central concern for Byres was the need for countries to accumulate an agrarian surplus, predominantly through the development of capitalism within agriculture, to provide capital for industrial investments, making the successful transition to industrial capitalism the main marker of a successful solution of the agrarian question. This Bernstein characterized as the agrarian question of capital and he went on to argue that there was 'no longer an agrarian question of capital on a world scale', nor of 'national' capitals (1996b, 202). Central to this argument was the suggestion that circuits of capital and commodities are no longer national, but are "mediated by the effects of the circuits of international capital and world markets, for each sector in any capitalist economy (central or peripheral)' (Bernstein 1996b, 42-3). Capitalism today, including agrarian capitalism, is global. Its development and economic circuits as delimited by national boundaries in the rigid manner we once thought about it has ceased to exist, including those involving agriculture. Important aspects of this are global food regimes (Friedmann and McMichael 1989); neo-liberal globalisation; global agribusiness, its development of the productive forces such as GM crops and its negative ecological consequences (Bernstein 2010b); and global commodity chains in food and other agricultural products (Bernstein and Campling 2006a, 2006b). Today, for Bernstein, the agrarian question of capital has either been completed or transcended (Bernstein 2016). ${ }^{4}$ Underlying this argument was Bernstein's prior characterization of the peasantry in the global South as petty commodity producers within dominant capitalist relations of production and reproduction: the 'transition to capitalism' in agriculture had already progressed further than Byres suggested, without leading to nationally based industrialization. Byres' contribution to this issue continues this discussion, sharpening the lines of their differences.

Seeing the agrarian economy and classes as already integrated into capitalism and emphasizing the 'bypassing' of the agrarian question for capital had serious

\footnotetext{
${ }^{3}$ See, for example, responses to Bernstein by Harriet Friedmann, Miguel Murmis and Philip McMichael (2006) in Canadian Journal of Development Studies, 27(4), and engagements in AkramLodhi and Kay 2010a and, especially, 2010b on 'Bernstein's Challenge'.

${ }^{4}$ In his most recent work Bernstein has gone further and argued that it is only the original transition in England that fits the above schema (2016).
} 
implications for Bernstein's analysis of rural petty commodity producers and labour. Drawing on writers such as Silver and Arrighi (2000), Davies (2006), Breman (1996) and Harriss-White (2003), and with the solution of the agrarian question in the classic manner which was supposed to lead to full-scale industrialization and proletarianization no longer on the cards, he found that global capitalism instead predominantly had resulted in fragmented classes, consisting of insecure, oppressive, informalized 'complex combinations of employment and self-employment' (Bernstein 2007, 6) (italics in original). The peasantry, more often than not, now reproduced itself as a combination of petty commodity producers and labourers without this leading to their full-scale transformation as a social class. The fragmented character of the 'classes of labour', both in terms of the wide mix of exploitative relations that they were part of and in terms of their segmentation along gender, ethnicity, linguistic and national lines meant that to Bernstein there was no reason to expect that they would be able to improve their position in the foreseeable future. Bernstein took a similarly level-headed view on what could be achieved within the agrarian sector and through this confronted both 'populists' and those advocating large scale capitalist agriculture as possible and beneficial for rural labour and petty commodity producers. To him, capital no longer needed land reforms to further the transition to capitalism in agriculture and to achieve industrialization; and the peasantry 'class' no longer exists. Redistributive land reforms might be relevant as a means to contribute to the subsistence of rural petty commodity producers - cum - labourers but that was all. Land reforms were now, at most, part of the 'agrarian question of labour' and not of the 'agrarian question of capital'.

One element explaining Bernstein's ability to move between fields and to make such incisive and long lasting contributions is his early take on interdisciplinarity. As he puts in the interview in this special issue:

you do not get interdisciplinarity by lumping disciplines together; you ... need a theoretical framework that is intrinsically capable of linking the economic, the social and the political.

Another element is that, while he is often seen or described as a theorist, a lot of his theoretical work comes from his consistently wide-ranging and voracious reading, including a lot of monographs, studies of agrarian change in different parts of the

\footnotetext{
${ }^{5}$ See especially the section 'agrarian questions of labour?' in Bernstein (2009b: 250-253).
} 
world, at different scales, from villages through to the national scale. This comes through in his careful engagement with and championing of others' work through book reviews and in his own essays; and crucially, his willingness to take on board criticism. But perhaps the most important element in explaining the longevity of Bernstein's contribution is his internalization of the method of historical materialism: moving from the abstract to the concrete, with its many determinations, and the dialectic between form and content. Never simply deploying Marx's abstract categories, Bernstein reminds us to rework them to an ever greater degree of concreteness in order to explain the social world: a comparative historical method that continues to heighten our understanding of the political economy of agrarian change.

Needless to say, the Journal of Agrarian Change and its editors are pleased to publish this collection of essays in honour of Henry Bernstein. Together with Terry Byres he has shaped $J A C$ and when they asked the new editorial team to take over in 2008 the new editors were aware of the honour, trust and challenge this offer implied. ${ }^{6}$ The high quality of the contributions to this special issue is a reflection of the continuing strength of $J A C$ 's distinctive political economy approach.

\section{References}

Akram-Lodhi, A.H., and C., Kay, 2010a. 'Surveying the Agrarian Question (Part 1): Unearthing Foundations, Exploring Diversity'. Journal of Peasant Studies, 37 (1), 177-202.

Akram-Lodhi, A.H., and C. Kay 2010b. 'Surveying the Agrarian Question (Part 2):

Current Debates and Beyond'. Journal of Peasant Studies, 37 (2), 255-284.

Bernstein, H., 1977. 'Notes on Capital and Peasantry'. Review of African Political Economy, 4 (10): 60-73.

Bernstein, H., 1996a. 'The political economy of the maize filière'. Journal of Peasant Studies, 23(2-3): 120-145.

Bernstein, H., 1996b. 'Agrarian questions then and now'. Journal of Peasant Studies, 24 (1-2): 22-59.

\footnotetext{
${ }^{6}$ See Bernstein and Byres (2008) and Johnston et al. (2008).
} 
Bernstein, H., 2000. 'Capitalism, colonialism, development'. In Poverty and Development in the Twenty-first Century, eds. T. Allen and A. Thomas, 241-270. Oxford: Oxford University Press.

Bernstein, H., 2007. 'Capital and labour from centre to margins'. Paper prepared for the Living on the Margins Conference, Stellenbosch, 26-28 March 2007.

http://urbandevelopment.yolasite.com/resources/Capital\%20and\%20Labou\%20in\%20 the\%20Margin\%20Bernstein.pdf [last accessed on 25 April 2016]

Bernstein, H., 2009a. 'V. I. Lenin and A. V. Chayanov: Looking Back, Looking Forward'. Journal of Peasant Studies 36(1): 55-81.

Bernstein, H. 2009b. 'Agrarian questions from transition to globalization'. In Peasants and Globalization. Political Economy, Rural Transformation and the Agrarian Question, eds. A. H. Akram-Lodhi and C. Kay, 239-261. London: Routledge.

Bernstein, H., 2010a. Class Dynamics of Agrarian Change. Halifax: Fernwood Publishing.

Bernstein, H., 2010b. 'Introduction: some questions concerning the productive forces'. In Productive Forces in Capitalist Agriculture. Political Economy and Political Ecology, H. Bernstein and P. Woodhouse, special issue of Journal of Agrarian Change, 10 (3): 300-314.

Bernstein, H., 2016. 'Revisiting agrarian transition: reflections on long histories and current realities'. In Agrarian Transition in India, ed. B. Mohanty. London: Routledge.

Bernstein, H. and T. Brass, eds., 1996. Agrarian Questions. Essays in Appreciation of TJ Byres, special issue of Journal of Peasant Studies, 24 (1-2): 1-250.

Bernstein, H. and T.J. Byres, 2008. 'From the retiring editors', Journal of Agrarian Change, 8 (1): 2.

Bernstein, H. and L. Campling, 2006a. 'Commodity studies and commodity fetishism I: Trading Down'. Journal of Agrarian Change, 6(2): 239-264.

Bernstein, H. and L. Campling, 2006b. 'Commodity studies and commodity fetishism II: profits with principles?'. Journal of Agrarian Change, 6(3): 414-447.

Bernstein, H., B. Crow, and H. Johnson eds., 1992. Rural Livelihoods: Crises and Responses, Oxford: Oxford University Press.

Breman, J., 1996. Footloose Labour. Working in India's Informal Economy. Cambridge: Cambridge University Press. 
Byres, T., 1991. 'The Agrarian Question and Differing Forms of Capitalist Agrarian Transition: An Essay with Reference to Asia'. In Rural Transformation in Asia, eds. Jan Breman and Sudipto Mundle, 3-76. Delhi: Oxford University Press.

Byres, T., 1996. Capitalism from Above and Capitalism from Below: An Essay in Comparative Political Economy. Basingstoke and London: Macmillan.

Davis, M., 2006. Planet of Slums. London: Verso.

Friedmann, H. and P. McMichael 1989. 'Agriculture and the state system: the rise and fall of national agricultures, 1870 to the present'. Sociologia Ruralis, 29 (2): 93-117.

Harriss-White, B., 2003. India Working. Essays on Society and Economy. Cambridge: Cambridge University Press.

Jansen, K., 2015. 'The debate on food sovereignty theory: agrarian capitalism, dispossession and agroecology'. Journal of Peasant Studies, 42 (1): 213-232.

Johnston, D. C. Kay, J. Lerche and C. Oya, 2008. 'From the new editors', Journal of Agrarian Change, 8 (1): 3-5.

McMichael, P., 'A comment on Henry Bernstein's way with peasants, and food sovereignty'. Journal of Peasant Studies, 42 (1): 193-204.

Silver, B.J. and G. Arrighi, 2000. 'Workers North and South'. In The Socialist Register 2001, eds L.Panitch and C.Leys. London: Merlin Press.

Warren, B., 1980. Imperialism. Pioneer of Capitalism. London: NBL and Verso. 